\title{
Bireysel Yenilikçiliğin İş Performansına Etkisi: Bir İşletme Örneği
}

\author{
Dursun Boz ${ }^{\mathrm{a}, \mathrm{b}}$, Emre Ergüzeloğluc ${ }^{\mathrm{c}}$, Cengiz Duran ${ }^{\mathrm{d}}$
}

\section{Özet}

Bireysel yenilikçilik en sade tanımıyla; bireysel olarak yenilikleri araştırıp bulma arzusudur. Diğer bir ifade ile bir yeniliği geliştirme, kabul etme ya da uygulamaya geçirme olarak tanımlanabilmektedir. İş performansı, işletmenin hedef ve amaçlarına ulaşma çabasına katkı sağlamak amacıyla personelin gösterdiği etkin davranışlar olarak tanımlanabilir. Daha genel bir ifade ile, bir çalışanın, işi ile ilgili hedeflenen amaçlara yönelik elde edebileceklerinin nitel ve nicel ifadesidir. Bu bağlamda çalışmanın amacı, bireysel yenilikçiliğin iş performansı üzerindeki etkisinin tespit edilmesidir. Bu amaç için Konya il merkezinde makine imalatı yapan bir işletmedeki beyaz ve mavi yakalı 200 gönüllü çalışana ulaşılmıştır. Elde edilen bulgular neticesinde bireysel yenilikçilik ve alt boyutlarının (değişime direnç alt boyutu hariç) iş performansı üzerinde pozitif ve anlamlı etkisi tespit edilmiştir. Demografik değişkenlerden cinsiyet bilgisinin; bireysel yenilikçilik ve iş performansı ile arasında herhangi bir anlamlı farklılık tespit edilememiştir. Diğer bir demografik değişken olan medeni durumu bilgisi ile bireysel yenilikçilik ve iş performansı arasında anlamlı farklılık tespit edilmiştir.
Anahtar Kelimeler

Yenilikçilik

Bireysel Yenilikçilik

Performans

İş Performansı

Makale Hakkında

Geliş Tarihi: 16.07.2019

Kabul Tarihi:12.20.2020

Doi: $10.18026 /$ cbayarsos.592342

\section{The Effect Of Individual Innovation On Work Performance: A Business Case}

\begin{abstract}
Individual innovation is in its simplest definition; it is the desire to research and find innovations individually. In other words, it can be defined as developing, accepting or implementing an innovation. Work performance can be defined as the effective behaviors of the staff in order to contribute to the effort of the enterprise to reach its goals and objectives. In more general terms, it is the qualitative and quantitative expression of what an employee can achieve for the intended purposes related to his or her work. In this context, the aim of the study is to determine the effect of individual innovation on work performance. For this purpose, 200 volunteers with white and blue collars were reached in a company manufacturing machinery in the city center of Konya. As a result of the findings, the positive and meaningful impact of individual innovation and its sub-dimensions (excluding the sub-dimension of resistance to change) on work performance was determined. Gender information from demographic variables; no significant difference was found between individual innovation and work performance. A significant difference was found between marital status information, another demographic variable, individual innovation and work performance.
\end{abstract}

Keywords

Innovation

Individual Innovation

Performance

Work Performance

About Article

Received: 16.07.2019

Accepted: 12.10.2020

Doi: 10.18026/cbayarsos.592342

\footnotetext{
a İletişim Yazarı: dursunboz@hotmail.com

b Dr. Dursun Boz, Kütahya Dumlupınar Üniversitesi, ORCID: 0000-0003-3206-8950

c Kütahya Dumlupınar Üniversitesi, ORCID: 0000-0002-9493-8790

d Doç. Dr. Kütahya Dumlupınar Üniversitesi, ORCID: 0000-0001-7910-0677
} 


\section{Giriş}

Hızla gelişen ve değişen dünyada yüksek rekabet ortamına rağmen işletmelerin; müşteri memnuniyetini sağlamaları, mal veya hizmet ürünlerini satabilmeleri, kâr elde edebilmeleri, pazardan pay kapabilmeleri, varlıklarını sürdürebilmeleri ve büyüyebilmeleri için piyasanın nabzını çok iyi tutmaları, müşterilerin ihtiyaç ve beklentilerini karşılayabilmeleri için yenilikçiliği kabullenmiş yönetim sistemlerini benimsemeleri gerekmektedir. İşletmelerin, personelin etkin ve verimli çalışabilmesi, pazarın beklentilerine cevap verebilen yeni ürünler geliştirilebilmesi, bu sayede rakiplerine üstünlük sağlayabilmeleri için bireysel yenilikçiliğin uygulanabilir olmasını sağlaması gerekmektedir. Bireysel yenilikçilik bir örgüt kültürü olarak benimsendiği takdirde tepe yönetiminden en alt seviyedeki çalışana kadar tüm personelin katılımı sağlanır. Bu katılım çalışanların iş performansını artırmasını sağlayacaktır. Bu amaçla bahse konu katılımın sağlanmasında; yenilikçiliğin tanımından, yenilikçilikle ilişkili kavramlardan, türlerinden, özelliklerinden ve öneminden bahsedilmiştir. Ayrıca; bireysel yenilikçiliğin, tarihsel süreç içerisindeki yayılımı ile benimsenmesinden, kategorilerinden, modellerinden, davranışsal eğiliminden ve önündeki engellerden değinilmiştir. Yenilikçiliğin iş/işletme çıktıları açısından önemli unsurlardan biri olan; performans, değerlendirme, değerlendirme yöntemleri, değerlendirme sonuçlarının kullanım alanları ve performans değerlendirme sisteminin taşıması gereken özellikler konuları ele alınmıştır. Ayrıca iş performansının tanımı, önemi, modelleri, boyutları ve etki eden faktörler konuları da irdelenmiştir.

\section{Bireysel Yenilikçilik}

Türk Dil Kurumu'nda yenilikçilik “yenilikçi olma durumu” olarak tanımlanır. Latince kökenli "nova", "yeni" kelimesine dayanan inovasyon, yani "yenilik" sözcüğü genelde yeni bir şeyin veya usulün tarifi ya da sunumu olarak tanımlanmaktadır (Yüksel, 2015:3). Bireysel yenilikçilik ise Hirschman (1980: 283-295)'e göre “yenilikleri kişisel olarak araştırıp elde etme isteği" olarak tanımlanmaktadır. Bu tanımda bütün bireylerin belirli seviyelerde inovatif oldukları ve yaşamları süresince yeni olduğunu kavradıkları düşüncelerin kabulüdür.

Bazı araştırmacılar (Jorde ve Teece, 1989: 48; Güleş ve Bülbül, 2004: 124; Jamrog vd., 2006: 5) bireysel yenilikçiliği, "satın alınan ürün ve hizmetlerin yapısını geliştirip değiştirerek yenilik yapmak" olarak kabul ederken, bazı araştırmacılar (Blake vd., 2003: 156; Jong ve Hartog, 2008: 4; Orhan, 2012: 15) için bireysel yenilikçilik, "yeniliği benimseme düzeyi" olarak tanımlanmıştır. Bireysel yenilikçilik çerçevesinde insanları yenilikçiler, erken davranan çoğunluk, erken benimseyenler, geç kalan çoğunluk olarak beş kategoride değerlendirmek mümkün olmaktadır (Neely ve Hii, 1998: 21). Bireysel yenilikçilik iki konu odaklı yenilikçilik ve genel yenilikçilik olarak kısımda incelenmektedir.

Gelişen ve değişen dünyanın, organizasyonların ve sektörlerin ihtiyaç duydukları en önemli birey özelliklerinden biri de yenilikçiliktir. Bireyler, bir işletmenin diş öğrenmesini sağlayan ve yenilikçilik stratejisine katkıda bulunan kaynak olarak görülmektedir. Dış kaynaklar sayesinde, bireyler bir işletmenin mevcut bilgi tabanını genişletmektedir. Bu şekilde bir işletme sürekli olarak yeni bilgiyi keşfederek kullanabilecektir. Bu da bilginin Schumpeteryen tarzında birleştirilmesini ifade etmektedir (Barirani vd., 2015:39-52). Bu birleşim Agarwal ve Prasad (1998)'e göre bireylerin kitlesel iletişim araçları vasıtasıyla topladıkları bilgileri sentezleyerek yenilikler hakkında tutum geliştirdiklerini ileri sürmektedir. Yenilikçilik seviyesi yüksek olan bireylerin, yeni fikirler hakkında aktif bilgi arayışı içerisinde oldukları 
değerlendirilmektedir. Bireysel yenilikçilik, bazı bireylerde var olan risk alma eğilimlerini simgeleyen bir unsur olarak da dikkate alınmaktadır. Yeniliklerin potansiyel benimseyicileri açısından, beklenen sonuçları hakkında belirsizlik oluşturduğu genel olarak kabul görmektedir (Lu vd., 2005). Ayrıca, bireylerin yenilikle ilgili bilişsel yorumları üzerindeki en büyük etkinin bireyin kendisi ile ilgili faktörler tarafından gerçekleştirileceği belirtilmektedir (Agarwal ve Prasad, 1998). Bu faktörler Leavitt ve Walton (1975) çalışmasında yenilikçi kişilerin özelliğini; yeni deneyimler ve diğer insanların görüşlerine açı olan, değerlendirmelerinde genellikle objektif olan, en önemlisi de aranmakta olan ya da rastlantısal karşılaştığı bilgiyi yapıcı kullanmayı bilen bireylerdir şeklinde sıralamışlardır.

Uzkurt (2008)'a göre bireysel yenilikçilik, bireyin yenilik istemesi ve davranışsal olarak da yenilikler için olumlu tepki vermesiyle fark oluşturmaktır. Yenilikçi kişi; konu, fikir ve uygulamaların yeni olmasının risklerini göze alabilen kişidir. Bu riskler davranışsal değer olarak da kabul edilen bireysel yenilikçiliğin bazı araştırmalarda kişinin yenilik benimsemesi süresi açısından; bazılarına göreyse bireysel yenilikçiliğe yatkınlı̆̆ın niteliği bağlamında değerlendirilmektedir (Oktuğ ve Özden, 2013).

\section{Bireysel Yenilikçilik Kategorileri}

Yenilikçilik, kişilerin yeni düşünceleri sistemdeki başka bireylerinden daha evvel kabulü şeklinde olarak tanımlanır (Rogers, 1995: 990). Sosyal sistemdeki bir yenilik tüm bireylerce aynı zamanda kabul edildiği görülmüş, kişilerin yeniliği kullanmaya farklı zamanlarda başladığı göz önünde bulundurularak kabul eden gruplar oluşturulmuştur. Yenilikçilik kategorisi Rogers (1995)'ın teorisini örnek alarak kuşkucular, yenilikçiler, gelenekçiler sorgulayıcılar ve öncüler şeklinde sınıflandırmıştır (Kılıçer, 2011: 27).

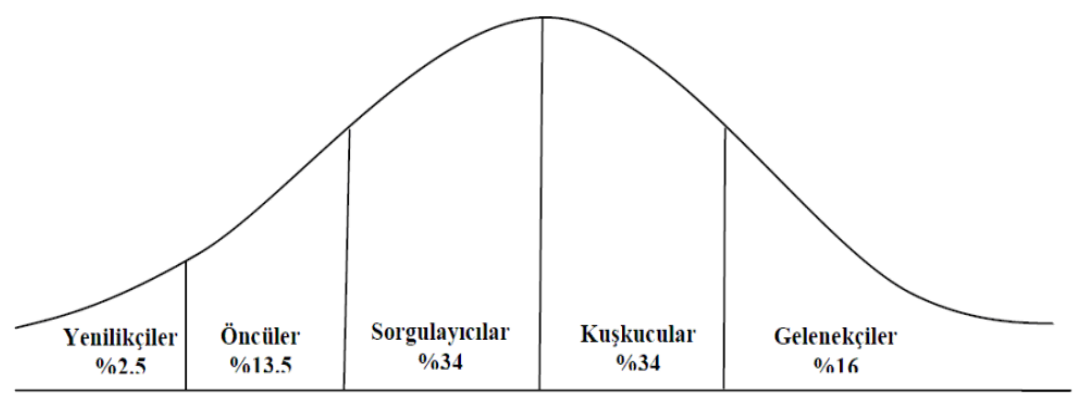

Şekil 1: Yenilikçilik kategorileri ve benimsenme düzeyleri Kaynak: (Rogers, 1995:163) Akt.

(Kılıçer 2011:27)

Yeniliği ilk benimseyenler "yenilikçiler" \%2,5 iken son benimseyenler gelenekçiler ise \%16'lık bir çoğunluktan oluşmaktadır (Kılıçer, 2011: 28). Örgütsel hedefler amacıyla yenilik yapanlar, sürdürülebilir rekabet üstünlüğü elde etmek kadar mühim bir konudur (Topcu vd., 2015). Yenilikçiler, tüm yenilik süreci boyunca ortaya attıkları düşüncelerle değil, uygulama içindeki liderlik tutumlarıyla rol oynarlar. Kişisel kabiliyetlerin inovatif tutumlara dönüşmesinde kişilerde olduğu kadar örgütler de önemlidir. Kişinin yeteneklerini cesaretli ve istekli biçimde yeni ürün, süreç ve hizmet üretilmesinde kullanımı işletmeler açısından çok önemlidir (Şimşek, 2002: 308). Öncü grup yeniliği ilk kullananlar olmaları nedeniyle yeniliğe karşı belirsizlikleri ve riski azaltarak deneyimlerini paylaşırlar. Öncüler teknoloji merkezli, vizyon sahibi, yol gösterici, risk alan ve değişim taraftarlarıdır (Özgür, 2010: 410. Sorgulayıcılar, "bekle gör" politikasını benimseyen yenilikleri pragmatik yönleriyle değerlendirirler (Greenhalgh vd., 2008: 102). Kuşkucuların en temel özellikleri çekingen ve 
şüpheci davranmalarıdır. Yeniliklere karşı kuşkuyla yaklaştıkları için bazı yenilikleri kabullenene kadar beklemektedirler. Bu sebepten dolayı diğer bireylerden daha geç kabul ederler. Kuşkuculara göre yeniliğin sosyal kurallarla uyumu, yeniliklere inanmak için önemlidir. Ayrıca yeniliklerin kabul edilebilmesi için kuşkuculara o yeniliğin güven vermesi gerekmektedir. (Rogers, 1995: 265). Gelenekçiler ise değişikliklere ve yeniliklere karş1 önyargılı olduklarından yenilikleri kabul etmek için sistemdeki diğer bireylerin bu yenilikleri denemesini ve başarılı sonuç almalarını bekler. Gelenekçilerin teknoloji kullanımı, sosyal iletişimi ve etkileşimleri sınırlı seviyededir. Bu sebeple yeniliklerle ilgili bilgiyi genel olarak güven duydukları kişilerden yüz yüze iletişimle öğrenirler (Kılıçer, 2011: 32).

Bireysel yenilikçiliğin alt faktörleri değişime direnç, fikir liderliği, deneyime açıklık ve risk alma olarak kabul edilebilir (Kılıçer, 2011: 27). Değişime direnç; yeniliği engelleme, güvenmeme, şüphe etme ve mesaiye geç kalma olarak ifade edilebilir (Şahin, 2011: 267). Kişinin risk almaktan kaçınan, bulunduğu statüsündeki üstünlüğünü kaybetmekten korkan tutum ve davranışlara girmesi değişime direnç davranışlarına örnektir (Bhatnagar vd., 2000: 100). Fikir liderliğinin davranışsal boyutu; kişileri, ilgili grup içinde diğer kişilerden öne çıkaran özelliklerini yansıtan, diğer kişilerin tutum ve davranışlarının değiştirilmesi, yönlendirilmesi ve etkileyebilmesidir. Fikir liderleri; kişilerin kusurlarına karşı hoş görülü olan, sürekli öğrenmek isteyen, farklı bir kişilik yapısına sahip olan, iş birlikçi ve değişime uyumlu kişilerdir. Deneyime açıklığın davranışsal boyutu; kişileri, yenilik arayan ve denemekten usanmayan istekliliktir. Bireysel yenilikçilik son boyutu risk almak olup bu boyut belirsizlik durumunda risk almaktır (McLean, 2005: 235). Yeloğlu (2007)'na göre girişimciliğin önündeki engeller; ekibe ait olan kaynak, mekan, zaman gibi engellerin veya engelleyicilerin baskısını hissetmektir. Bu his inovatif olmayı negatif etkilemektedir.

\section{İş Performansı}

"Performans" sözcüğü; Fransızca kökenli olup batı temelli kelimeler grubundadır. Sözlükte; yapılan iş, icraat, uygulama, şahsın yapabileceği en iyi derece veya bir işi, oyunu, eseri vb. sergilerken gösterilen çaba; bir durumu veya olayı başarma gücü ve isteği olarak tanımlanmaktadır (www.tdk.org). Bir hedefe ulaşabilmek için gösterilen gayret veya bir işi yerine getirme başarısı olarak ifade edilebilir (Akal, 1992:1). Performans, kişinin amaçlarına ulaşabilmesi için sahip olduğu bilgi ve becerilerini ne kadar kullanabildiğini ifade eder. Başka bir ifadeyle; bireyin kapasitesini, belli bir zaman içerisinde, istenilen başarı seviyesine göre ne ölçüde başarı ile tamamlayabildiğinin oran olarak ifade edilmesidir (Akal, 2000). İnsan kaynakları yönetimi açısından performans, kişiyle işletme amaçlarının birbiriyle etkileşmesinin neticesi olarak adlandırılabilir (Çalık, 2003:7). Bu kavramla ilgili kaynaklar incelendiğinde, çeşitli tanımlar ve kuramların olduğu görülmektedir.

Basit anlamıyla performans bir işgörenin, bir ekibin veya bir örgütün hedeflenen amaçlara yönelik neleri temin edebileceğinin nitel ve nicel ifadesidir (Baş ve Artar, 1991:13). En genel tanımıyla iş performansı, çalışanların işletmede sergiledikleri davranışların tümü ve en önemli unsurudur. İşletmenin başarısı çalışanlarının iş performansına bağlıdır. İş performansı, kişi tarafından üretilen, objektif ve sonuç odaklı, bir performans ölçütü olarak sunulan satış geliri ile temsil edilmektedir. Satış çalışmalarının kendisi üzerinde odaklanan sonuç dışında niceliksel ölçüt, genellikle değerlendirenin gözlemini içeren davranış odaklı bir önlemden daha net ve tarafsızdır (Wan-Jing ve Tung, 2011: 278). Çalışanların tavırlarını analiz etmek, iş kalitesini arttırmak ve denetlemek gelecek zamana dair tahminlerde bulunmak işletmelerin amaçları arasındadır. İşletmeler bu amaçları yüksek oranda gerçekleştirme seviyesinde 
etkinliğini sağlayabilirler. İşletmenin varlığını sürdürebilmesi ve başarılı olabilmesi için performansın yükseltilmesi, birçok etkene bağlıdır (Özdemir, 2017: 44).

İş performansı, belirlenen işin hangi kalitede yapıldığını anlatır. Kişisel açıdan bakıldığında iş performansı, işletmenin amacına ulaşma çabasına katkı sağlamak amacıyla personelin gösterdiği davranışlar olarak tanımlanabilir (Sonnentag ve Frese, 2002: 5). Diğer bir tanımda ise iş performansı, çalışanlara ödenen ücret karşılığında vermeleri gereken emek olarak da değerlendirilmiştir. İş performansı, işletmelerin pek çoğunun odaklanmak için düşünmesi gereken en önemli faktörlerden birisidir (Safaria vd., 2012: 160). Bu faktörler işletme hedeflerinin gerçekleştirilmesinde çalışanların katkıları bağlamında önemlidir. İşletmelerde kişisel gelişim çok boyutlu iletişim kanallarının kurulmasıyla sağlanarak örgütsel etkinliğe katkı yapar. Performans değerlemede ölçütler hedeflerin tutturulup tutturulamayacağın kontrolü ile değerlendirmesinde kullanılır. Erdemir (2013)'e göre; performansın bireysel beklentiyle örgütsel amaç arasında kurulan ilişkinin sonucunda oluşması görüldüğü üzere, çalışanların bireysel performansıyla alakalı yapılmış olan birçok tanımın ortak noktasıdır. İş görenlerin nicel ve nitel açıdan hedeflerine ulaşabilmeleri bakımından örgütsel iklim ile ilişkili bazı psikolojik şartların da oluşması gerekmektedir. İşgörene maaş ve kariyer gelişimi gibi maddi olanakların sağlanmasının yanı sıra kurumsal destek duygusunun kazandırılması, kısaca kendini gerçekleştirme olanağı verecek bir örgütsel iklimin oluşturulmasının önemi büyüktür (Erdemir, 2013:4).

Borman ve Motowidlo tarafından iş performansının boyutlarını belirlemek için yapılan çalışma, bu alanda temel olarak kabul edilebilecek bir yaklaşımdır. Bu yaklaşıma göre, iki tür işgören davranışı ortaya konmaktadır. Bunlar, bağlamsal performans ve görev performansıdır. İşletmenin etkinliğine katkıda bulunduğu varsayılan bu davranış şekilleri, örgütsel davranış açısından çok önemli iki unsurdur (Kurt, 2013: 7).

\section{Bağlamsal Performans}

İşin tanımında yer alan eylemlerin tamamı iş performansını kapsamaz. İşgörenlerin aralarındaki etkileşimleri sonucu ortaya çıkan eylemler de performans kavramı içinde yer alır. İşgörenlerin motivasyonu sonucu oluşan faaliyetler, bağlamsal performans olarak ifade edilir (Erkoç, 2015: 15). Scotter ve Motowidlo bu konuda yaptıkları çalışma ile bağlamsal performans iki farklı boyutta incelenmiştir. Bu boyutlardan ilki olan kolaylaştırıcılık; çalışanların kendi aralarındaki ilişkiler kapsamında değerlendirilen eylemleri ve işgören performansını destekleyen davranışları içine alır. Diğer boyut işe adanma ise daha çok işgörenlerin işlerine istekli olmaları, onu içselleştirmeleri ve istenilen hedeflere ulaşmaları için kurallara uymaları gibi durumları kapsar (Ünlü ve Yürür, 2011: 185).

\section{Görev Performansı}

$\mathrm{Bu}$ performans ise görev kapsamında daha önce belirlenmiş olan ölçütleri karşılayacak şekilde, amacın gerçekleştirilmesi ve görevin yerine getirilmesi yönünde ortaya konulan hizmet, mal veya düşünceyi ifade etmektedir. Bu kapsamda göreve ilişkin performansın daha çok yapılan işin teknik ve ihtisas kısmı ile ilgili olduğu ifade edilebilir (Jawahar ve Carr, 2007: 330). Görev performansı, mesleki yeterlilik düzeyi ile doğrudan ilgilidir. Ayrıca görev tanımındaki belirginlik, çalışma ortamının uygunluğu ve ahlaki özellikler görev performansını etkileyen öğelerdir. Örnek olarak; görev tanımının oluşturulmasındaki güçlük, planlanan performans seviyesinin belirlenmesine negatif yönde etki edecektir. Örgütün 
amaçlarına ulaşmasında sadece işe yönelik davranışlar değil; işe yönelik olmayan davranışlar da göz önünde bulundurulmalıdır. Örgütsel bağlılık, ekip çalışması, gönüllülük ve yardımseverlik gibi davranışlar, doğrudan işe yönelik olmayan görevler arasında yer almaktadır (Kılıç, 2006: 175).

\section{Araştırma Modeli, Veri ve Yöntem}

$\mathrm{Bu}$ araştırmanın amacı bireysel yenilikçiliğin iş performansı ile etkileşimini belirlemektir. Araştırmanın modeli, hipotezleri ve yöntemi aşağıda sunulmuştur.

\section{Bireysel Yenilikçilik (BY) İşs Performansı (IP)}

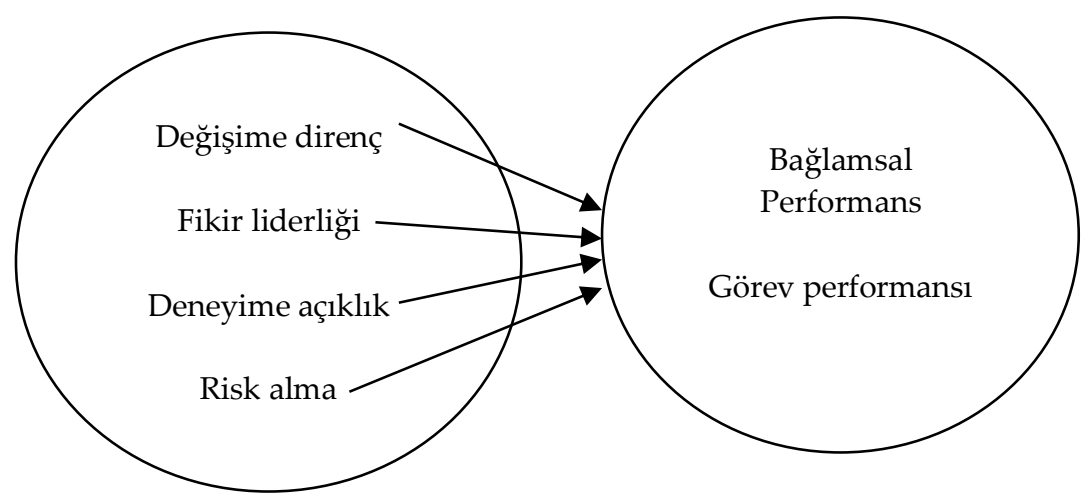

Araştırmaya ait hipotezler şunlardır;

$\mathrm{H}_{1}$ : Bireysel yenilikçilik; iş performansı üzerinde anlamlı etkiye sahiptir

$\mathrm{H}_{1 a}$ Bireysel yenilikçiliğin alt faktörü değişime direnç; iş performansı üzerinde anlamlı etkiye sahiptir

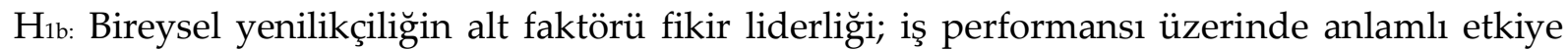
sahiptir

H1c: Bireysel yenilikçiliğin alt faktörü deneyime açılık; iş performansı üzerinde anlamlı etkiye sahiptir

$\mathrm{H}_{1 d:}$ Bireysel yenilikçiliğin alt faktörü risk alma; iş performansı üzerinde anlamlı etkiye sahiptir

Araştırmada; bireysel yenilikçiliğin iş performansına etkisinin araştırılması amaçlanmış ve uygulama alanı olarak Konya'da makine imalatı yapan bir işletmenin beyaz ve mavi yakalı çalışanları belirlenmiştir. Yapılan inceleme ve araştırmada 2 ölçek ile demografik değişkenlerden oluşan veri seti kullanılmıştır. Bireysel yenilikçilik ölçeği 20 ifadeden, iş performansı ölçeği 23 ifadeden oluşmaktadır. Toplamda 43 ifade likert tipinde ve 8 adet demografik özellik içeren ifadelerden oluşan anket 200 beyaz ve mavi yakalıya uygulanmıştır. Araştırmada kullanılan ilk ölçek bireysel yenilikçilik ölçeği; Hurt vd. (1977) geliştirdiği ve Türkçe'ye K1lıçer (2011) tarafından uyarlanan ölçektir. İkincisi olan iş performansı ölçeği ise; Goodman and Svyantek (1999) tarafından geliştirilen ve Doğan (2005) tarafından sadeleştirilen ve Özer (2018) çalışmasında kullandığı ölçektir. Araştırmada verilerin analizi için SPSS (18.0) programı kullanılmıştır. Anket sorularının uzun olması, iş yoğunluğu ve bazı katılımcıların soruları uzun ve sıkıcı bulmaları en önemli kısıtlardandır. 


\section{Bulgular}

Araştırma kapsamındaki makine imalatında faaliyet gösteren işletmedeki 200 beyaz ve mavi yakalı çalışandan oluşturulan veri setiyle demografik özellikleri, kullanılan ölçeklerin faktör analizi, örneklem yeterliliği, güvenilirlik analizleri, fark testleri, korelasyon analizi, regresyon analizleri vb. ile yorumlanması yer almaktadır.

Tablo 1: Demografik özellikler

\begin{tabular}{|c|c|c|c|c|c|}
\hline Cinsiyet & Frekans & $\%$ & Gelir TL. & Frekans & $\%$ \\
\hline Kadın & 14 & 7,0 & $0-1700$ & 57 & 28,5 \\
\hline Erkek & 186 & 93,0 & $1701-3400$ & 120 & 60,0 \\
\hline Toplam & 200 & 100,0 & $3401-5000$ & 22 & 11,0 \\
\hline MedeniDurum & Frekans & $\%$ & $5001-7000$ & 1 & 0,5 \\
\hline Evli & 154 & 77,0 & Toplam & 200 & 100,0 \\
\hline Bekar & 46 & 23,0 & Eğitim & Frekans & $\%$ \\
\hline Toplam & 200 & 100,0 & İlköğretim & 73 & 36,5 \\
\hline Statü & Frekans & $\%$ & Lise & 46 & 23,0 \\
\hline Mavi yakalı & 150 & 75,0 & Ön Lisans & 52 & 26,0 \\
\hline Beyaz yakalı & 50 & 25,0 & Lisans & 24 & 12,0 \\
\hline \multirow[t]{2}{*}{ Toplam } & 200 & 100,0 & Lisansüstü & 5 & 2,5 \\
\hline & & & Toplam & 200 & 100,0 \\
\hline Yaş & Frekans & $\%$ & Çalışma Süresi & Frekans & $\%$ \\
\hline $18-28$ & 53 & 26,5 & 1 yildan az & 28 & 14,0 \\
\hline $29-38$ & 70 & 35,0 & $1-5$ y1l & 73 & 36,5 \\
\hline $39-46$ & 54 & 27,0 & 6-10 y1l & 35 & 17,5 \\
\hline $47-53$ & 18 & 9,0 & $11-20 \mathrm{y} 1 \mathrm{l}$ & 49 & 24,5 \\
\hline 54 ve üzeri & 5 & 2,5 & 21y1l ve üst & 15 & 7,5 \\
\hline Toplam & 200 & 100,0 & Toplam & 200 & 100,0 \\
\hline
\end{tabular}

Araştırmaya katılanların \%7,0'ı kadın, \%93,0'ının erkek olduğu görülmektedir. Araştırmaya katılanların \%77,0'1 evli, \%23,0'ının bekâr olduğu görülmektedir. Araştırmaya katılanların $\% 75,0$ '1 mavi yakalı, \%25,0'ının beyaz yakalı olduğu görülmektedir. Araştırmaya katılanların \%26,5'i 18-28 yaş aralığında, \%35,0' 1 28-38 yaş aralığında, \%27,0'1 39-46 yaş aralığında, \%9,0'1 47-53 yaş aralığında, \%2,5'inin 54 ve üzeri yaş aralığında olduğu görülmektedir. Araştırmaya katılanların aylık gelirlerinin \%28,5'i 0-1700 TL. arasında, \%60,0'1 1701-3400 TL. arasında, $\% 11,0$ '1 3401-5000 TL. arasında, \%0,5'inin 5001-7000 TL. arasında olduğu görülmektedir. Araştırmaya katılanların öğrenim durumları \%36,5'i ilköğretim, \%23,0'1 lise, \%26,0'1 ön lisans, $\% 12,0^{\prime} 1$ lisans, \%2,5'inin lisansüstü mezunu olduğu görülmektedir. Araştırmaya katılanların kurumda çalışma sürelerine bakıldığında \%14,0'1 1yıldan az, \%36,5' i 1-5 yıl arası, \%17,5'i 6-10 yıl arası, \%24,5'i 11-20 yıl arası, \%7,5'inin 21yıl ve üzerindedir.

\section{Ölçeklerin Faktör Analizi İle Geçerlilik ve Güvenilirlik Analizi}

Çalışmada kullanılan bireysel yenilikçilik (BY) ve iş performansı (IP) ölçeğine açımlayıcı (keşfedici) faktör analizi ve güvenilirlik analizi yapılmıştır. Açımlayıcı faktör analizi faktörler arasındaki korelasyon ilişkilerini bulmaya çalışır. Araştırmadan elde edilen verilerin faktör analizine uygunluğu amacıyla Kaiser-Meyer-Olkin (KMO) örneklem yeterliliği ve Bartlett 
Küresellik testi yapılmıştır. KMO örneklem yeterlilik testinde uygun olan alt sınır değeri 0,50'dir. Bu değerin 0,80 - 0,90 arasında olması çok iyi olarak değerlendirilmektedir. Normal dağılımın göstergesi olarak Eğiklik/Basıklık değerleri -3 ile +3 arasında olmalıdır. (Kalaycı, 2010:322). Ortak varyansın açıklanmasında 200 üstü örneklemlerde 0,50'den büyük olması beklenmelidir (Field 2007). Faktörlerin korelasyona bağlı iç tutarlıkları için Cronbach's Alpha katsayısının 0,80'den yüksek olması iyi olarak değerlendirilebilir (Büyüköztürk, 2007). Araştırmada kullanılan 2 ölçek için de eğik döndürme (Promax), faktör yükleri 0,45 üzerinde, çıkarım metodu olarak temel bileşenler (Principal Compenents) seçilerek faktör analizi yapılmıştır.

Tablo 2: Faktör Analizi BY ölçeği

İP ölçeği

\begin{tabular}{|c|c|c|c|c|c|c|c|}
\hline \multirow{2}{*}{ İfadeler } & \multicolumn{4}{|c|}{ Bileşenler } & \multirow{2}{*}{ İfadeler } & \multicolumn{2}{|c|}{ Bileşenler } \\
\hline & 1 & 2 & 3 & 4 & & 1 & 2 \\
\hline 3 & 0,814 & & & & 21 & 0,923 & \\
\hline 5 & 0,748 & & & & 22 & 0,867 & \\
\hline 8 & 0,735 & & & & 28 & 0,834 & \\
\hline 4 & 0,728 & & & & 23 & 0,832 & \\
\hline 2 & 0,722 & & & & 29 & 0,824 & \\
\hline 1 & 0,668 & & & & 24 & 0,742 & \\
\hline 6 & 0,615 & & & & 38 & 0,718 & \\
\hline 7 & 0,596 & & & & 27 & 0,610 & \\
\hline 14 & & 0,789 & & & 26 & 0,584 & \\
\hline 15 & & 0,764 & & & 40 & 0,572 & \\
\hline 16 & & 0,698 & & & 39 & 0,549 & \\
\hline 17 & & 0,683 & & & 31 & & 0,927 \\
\hline 18 & & 0,666 & & & 36 & & 0,819 \\
\hline 10 & & & 0,841 & & 25 & & 0,814 \\
\hline 9 & & & 0,730 & & 35 & & 0,710 \\
\hline 13 & & & 0,563 & & 32 & & 0,671 \\
\hline 11 & & & 0,501 & & 33 & & 0,580 \\
\hline 12 & & & 0,492 & & 30 & & 0,462 \\
\hline 20 & & & & 0,766 & & & \\
\hline 19 & & & & 0,654 & & & \\
\hline
\end{tabular}

Tabloda görüldüğü üzere BY ölçeğinin 4 faktörlü ve 20 ifadeden oluşan ölçeğin faktör yükleri ,492 ile,841 arasında değişmektedir. 4 faktörlü ve 20 ifadeden oluşan ölçeğin toplam varyansın \%62,685' ini açıkladığ 1 tespit edilmiştir. İP ölçeği ise teorik olarak eşleşmeyen ve madde yükleri düşük (34, 37, 41, 42 ve 43.) ifadeler çıkarılarak tekrar yapılan faktör analizinde faktör yükleri ,462 ile,927 arasında değişmektedir. 2 faktörlü ve 18 ifadeden oluşan ölçeğin toplam varyansın $\% 57,591$ 'ini açıkladığ 1 tespit edilmiştir. 
Tablo 3: KMO ve Bartlett's TestiBY Ölçeği İP Ölçeği

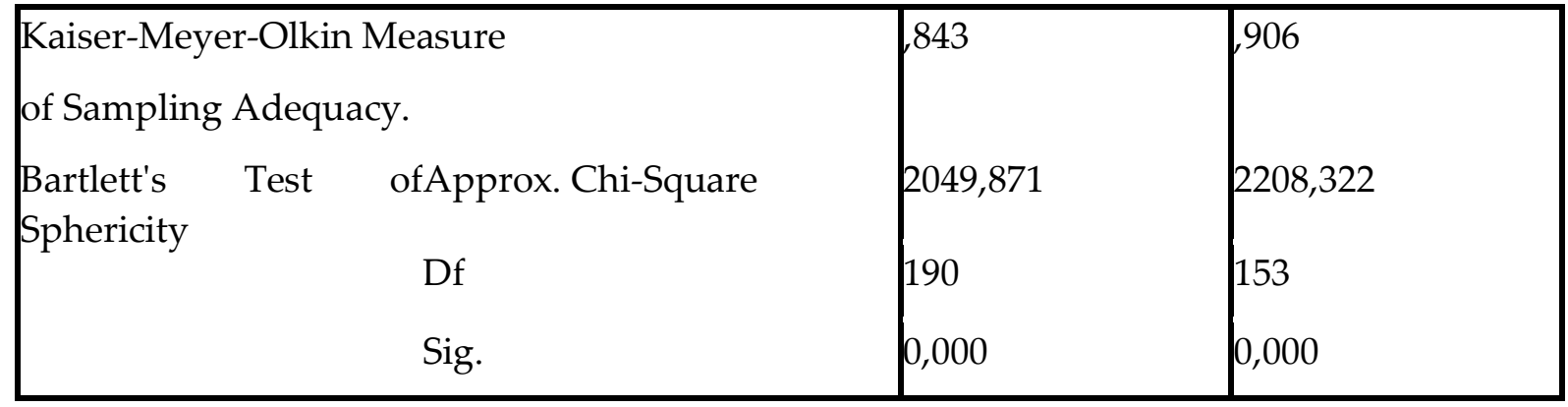

Tabloya göre BY ölçeğinin 3 faktörlü ve 20 ifadeden oluşan ölçeğin KMO değeri, 843 ile çok iyi olduğu tespit edilmiştir. İP ölçeğinin ise 2 faktörlü ve 18 ifadeden oluşan ölçeğin KMO değeri ,906 ile çok iyi olduğu tespit edilmiştir.

Tablo 4: Güvenilirlik analizi

\begin{tabular}{|l|l|l|}
\hline Cronbach's Alpha & İfade sayısı \\
\hline BY Ölçeği & 798 & 20 \\
\hline İP Ölçeği & 926 & 18 \\
\hline
\end{tabular}

Tabloya göre BY ölçeği Güvenilirlik katsayısı Cronbach's Alpha Değeri ,798 sonucu ile iyidir. İP ölçeği ise Güvenilirlik katsayısı Cronbach's Alpha Değeri ,926 sonucu ile çok iyidir.

\section{Demografik Özellikler ile değişkenlere ait T-Testleri ve Anova Testleri}

$\mathrm{Bu}$ kısımda bazı demografik özellikler ile bireysel yenilikçilik ve iş performansı arasındaki ilişkiler t-testi ve Anova ile analiz edilmiştir. T-Testinin yapılma amacı iki örneklem arasındaki ortalamaların önemli seviyede farklılık olup/olmadığının ayrımında kullanılması içindir (Kalaycı, 2010: 74). Tek yönlü varyans (ANOVA) yapılmasının amacı ise ikiden fazla örneklem grubu arasındaki ortalamalar arasında farklılık olup/olmadığının ayrımının belirlenmesidir (Kalayc1, 2010: 131).

Tablo 5: Medeni Durum ve Cinsiyet T-Testi

\begin{tabular}{|l|l|l|l|l|l|l|}
\hline Değişkenler & Medeni Durum & $\mathbf{N}$ & Ort. & S.H. & $\mathbf{t}$ & $\mathbf{P}$ \\
\hline \multirow{2}{*}{ BY } & Evli & 154 & 3,5080 &, 49387 & 2,979 &, 003 \\
\cline { 2 - 7 } & Bekar & 46 & 3,2596 &, 50365 & 2,947 &, 004 \\
\hline \multirow{2}{*}{ IP } & Evli & 154 & 4,2209 &, 53688 & 3,295 &, 001 \\
\cline { 2 - 7 } & Bekar & 46 & 3,9084 &, 64964 & 2,973 &, 004 \\
\hline \multirow{2}{*}{ Değiş } & Cinsiyet & $\mathbf{N}$ & Ort. & S.H. & $\mathbf{t}$ & $\mathbf{P}$ \\
\hline \multirow{2}{*}{ BY } & Kadın & 14 & 3,2554 &, 43919 & $-1,504$ &, 134 \\
\cline { 2 - 7 } & Erkek & 186 & 3,4656 &, 50848 & $-1,707$ &, 108 \\
\hline \multirow{2}{*}{ İP } & Kadın & 14 & 4,0211 &, 50723 &,- 858 &, 392 \\
\cline { 2 - 7 } & Erkek & 186 & 4,1587 &, 58337 &,- 968 &, 348 \\
\hline
\end{tabular}

Tabloya göre $\mathrm{p}<0,05$ anlamlılık düzeyinde bireysel yenilikçilik ve iş performansı konusunda evli olanların bekâr olanlara göre anlamlı farklılık vardır. Bu durum evli olan katılımcıların düzenli hayatlarının iş yaşamındaki yenilikçilik ve iş performansındaki yüksek algılamalarıyla açıklanabilir. İşletme yöneticilerinin özellikle insan kaynağı seçiminde daha yüksek bireysel yenilik ve iş performansı için bu durumu göz ardı etmemelidir. Ayrıca cinsiyet 
ile ilgili $p<0,05$ anlamlılık düzeyinde bireysel yenilikçilik ve iş performansı konusunda anlamlı farklılık tespit edilememiştir.

\section{Yaş ile Bireysel Yenilikçilik ve İş Performansı arasında ANOVA Bulguları}

Çalışmaya katılanların bireysel yenilikçilik ve iş performansıyla alakalı algıları yaş ile kurumda çalışma süresi değişkeni baz alınarak gruplandırılarak ve "Tek Yönlü ANOVA" yapılmış ve tabloda belirtilmiştir.

Tablo 6: Yaş-Kurumda Çalışma Süresi ile Bireysel Yenilikçilik ve İş Performansı arasında ANOVA

\begin{tabular}{|c|c|c|c|c|c|c|}
\hline \multicolumn{2}{|c|}{ Yaş } & \multirow{2}{*}{$\begin{array}{l}\text { Kareler Top. } \\
1,732 \\
49,184 \\
50,916\end{array}$} & \multirow{2}{*}{$\begin{array}{l}\text { Serbestlik Der } \\
4 \\
195 \\
199\end{array}$} & \multirow{2}{*}{$\begin{array}{l}\text { Kareler } \\
\text { Ort. } \\
433 \\
252\end{array}$} & \multirow{2}{*}{$\frac{\mathrm{f}}{1,717}$} & \multirow{2}{*}{$\frac{P}{148}$} \\
\hline BY & $\begin{array}{l}\text { Gruplararası } \\
\text { Grupiçi } \\
\text { Toplam }\end{array}$ & & & & & \\
\hline İP & $\begin{array}{l}\text { Gruplararası } \\
\text { Grupiçi } \\
\text { Top. }\end{array}$ & $\begin{array}{l}6,924 \\
59,627 \\
66,551 \\
\end{array}$ & $\begin{array}{l}4 \\
195 \\
199\end{array}$ & $\begin{array}{l}1,731 \\
, 306\end{array}$ & 5,661 & , 000 \\
\hline & nda çalışma süresi & Kareler Top. & $\begin{array}{l}\text { Serbestlik } \\
\text { Der. }\end{array}$ & $\begin{array}{l}\text { Kareler } \\
\text { Ort. }\end{array}$ & $\mathrm{F}$ & $P$ \\
\hline $\mathrm{BY}$ & $\begin{array}{l}\text { Gruplararası } \\
\text { Grupiçi } \\
\text { Top. }\end{array}$ & $\begin{array}{l}1,510 \\
49,405 \\
50,916\end{array}$ & $\begin{array}{l}4 \\
195 \\
199\end{array}$ & $\begin{array}{l}378 \\
\text {,253 }\end{array}$ & 1,490 & ,207 \\
\hline İP & $\begin{array}{l}\text { Gruplararası } \\
\text { Grupiçi } \\
\text { Top. }\end{array}$ & $\begin{array}{l}5,448 \\
61,103 \\
66,551\end{array}$ & $\begin{array}{l}4 \\
195 \\
199\end{array}$ & $\begin{array}{l}1,362 \\
, 313\end{array}$ & 4,346 & ,002 \\
\hline
\end{tabular}

Tabloya göre yaş ve kurumda çalışma süresi bilgisinin iş performansı üzerinde anlamlılık değeri $\mathrm{p}<0,05$ olduğundan anlamlı bir fark olduğu görülmektedir. Bu anlamlı farklılı̆̆ın grupların hangisinde olduğunu tespiti için Tablo 4.21.'de sunulduğu üzere Post Hoc Tukey testi yapılmıştır.

Tablo 7: Yaş ve Kurumda çalışma süresi ile İş Performansı arasında çoklu karşılaştırma testi (Post Hoc.Tukey)

\begin{tabular}{|c|c|c|c|c|c|c|}
\hline \multirow[t]{2}{*}{ (I) Yas } & \multirow[t]{2}{*}{ (J) Yasınız } & \multirow{2}{*}{$\begin{array}{l}\text { Ort.Fark1 (I- } \\
\text { J) }\end{array}$} & \multirow[b]{2}{*}{ S.H. } & \multirow[b]{2}{*}{$\mathrm{P}$} & \multicolumn{2}{|c|}{ 95\% Güvenaralığ1 } \\
\hline & & & & & Altsinir & Üstsınır \\
\hline \multirow[t]{4}{*}{$18-28$} & $29-38$ &,- 27317 & , 10069 & ,056 &,- 5504 & ,0041 \\
\hline & $39-46$ &,$- 47790^{*}$ & ,10692 & ,000 &,- 7723 &,- 1835 \\
\hline & $47-53$ &,$- 46849 *$ & ,15085 & ,018 &,- 8839 &,- 0531 \\
\hline & 54veüst &,- 21108 & 25870 & ,925 &,- 9234 &, 5012 \\
\hline
\end{tabular}




\begin{tabular}{|ll|l|l|l|l|l|}
\hline (I)KurumCalisma & (J)KurumCalisma & $\begin{array}{l}\text { Ort.Fark1 } \\
\text { (I-J) }\end{array}$ & \multirow{2}{*}{ S.H. } & \multirow{2}{*}{$\mathrm{P}$} & & \multicolumn{2}{|l|}{ 95\% Güvenaralığ1 } \\
\cline { 6 - 7 } & & & & & Altsınır & Üstsınır \\
\hline 1 yıldan az & 1-5yıl &,- 25330 &, 12443 &, 253 &,- 5959 &, 0893 \\
& 6-10yıl &,- 29396 &, 14193 &, 237 &,- 6848 &, 0968 \\
& 11-20yıl &,$- 52411^{*}$ &, 13261 &, 001 &,- 8893 &,- 1590 \\
& 21 veüst &,- 44434 &, 17911 &, 099 &,- 9375 &, 0488 \\
\hline
\end{tabular}

Post Hoc Tukey Testi çoklu karşılaştırmalara imkanı veren (Kalaycı, 2010) bir testtir. İş performansı konusunda 18-28 yaş aralığında çalışanların; 39-46 ve 47-53 yaş aralığında çalışanlara göre $\mathrm{p}<0,05$ anlamlılık düzeyinde negatif yönlü anlamlı farklılığı göstermektedir. $\mathrm{Bu}$ farklılık 18-28 yaş aralığında çalışanların iş yaşamında yeni oldukları ve bunu iş performansına yansıtamadıkları ile açıklanabilir. Ayrıca, iş performansı konusunda 1 yıl ve altı çalışanların 11-20 yıl arası çalışanlara göre $p<0,05$ anlamlılık düzeyinde negatif yönlü anlamlı farklılık göstermektedir. Bu farklılık işe yeni başlayan çalışanların işe oryantasyon sorunlarından dolayı iş performansının düşüklüğü ile açıklanabilir.

Tablo 8. Anket İfadelerinin Aritmetik Ortalaması

\begin{tabular}{|c|c|c|c|c|c|c|c|c|}
\hline$\overline{\text { Iffade }}$ & Ort. & S.H. & İfade & Ort. & S.H. & İfade & Ort. & S.H. \\
\hline 1 & 2,98 & 1,1624 & 16 & 3,67 & 0,9366 & 31 & 3,72 & 1,1447 \\
\hline 2 & 2,52 & 1,1903 & 17 & 3,79 & 0,9329 & 32 & 4,17 & 0,9176 \\
\hline 3 & 2,55 & 1,1766 & 18 & 4,08 & 0,8645 & 33 & 4,08 & 0,8793 \\
\hline 4 & 2,48 & 1,1818 & 19 & 3,99 & 0,9641 & 34 & 4,09 & 0,8577 \\
\hline 5 & 2,34 & 1,1916 & 20 & 3,48 & 1,1162 & 35 & 3,93 & 0,9454 \\
\hline 6 & 2,45 & 1,2307 & 21 & 4,36 & 0,7438 & 36 & 3,68 & 1,0511 \\
\hline 7 & 2,91 & 1,2609 & 22 & 4,28 & 0,7100 & 37 & 4,28 & 0,8516 \\
\hline 8 & 2,33 & 1,1428 & 23 & 4,29 & 0,7527 & 38 & 4,17 & 0,9357 \\
\hline 9 & 3,33 & 1,0748 & 24 & 4,23 & 0,7729 & 39 & 3,98 & 0,9266 \\
\hline 10 & 3,67 & 0,9674 & 25 & 3,76 & 0,9537 & 40 & 4,19 & \begin{tabular}{|l|}
1,0769 \\
\end{tabular} \\
\hline 11 & 3,69 & 0,8530 & 26 & 3,76 & 0,9147 & 41 & 2,42 & 1,4644 \\
\hline 12 & 3,63 & 0,8928 & 27 & 3,86 & 0,9136 & 42 & 3,68 & \begin{tabular}{|l|}
1,2757 \\
\end{tabular} \\
\hline 13 & 3,74 & 0,9784 & 28 & 4,23 & 0,7729 & 43 & 4,20 & \begin{tabular}{|l|}
1,0209 \\
\end{tabular} \\
\hline 14 & 3,93 & 0,8826 & 29 & 4,15 & 0,8252 & & & \\
\hline 15 & 4,00 & 0,8682 & 30 & 4,03 & 0,9639 & & & \\
\hline
\end{tabular}

Anketteki ilk 23 ifade bireysel yenilikçiği, diğgerleri de iş performansını ölçmek için kullanılan ifadelerin aritmetik ortalamalarıdır. Anketteki 8.ifade (yeniliklere karşı şüphecilik $\bar{x}=2,33$ ), 5.ifade (yeni iş yapış yöntemlerinde isteksizlik $\bar{x}=2,34$ ), 41. ifade (mola zamanlarında uzun telefon görüşmesi $\bar{x}=2,42$ ), 6.ifade (eski usul ve yöntemlerle iş yapma $\bar{x}=2,45$ ), 4.ifade (yenilikleri son kabul eden $\bar{x}=2,48$ ), 2.ifade (yeni icat ve düşüncelere karş1 şüphe $\bar{x}=2,52$ ), 3.ifade (yeni fikirlere itibar etmeme $\bar{x}=2,55$ ) ve 7 .ifade (diğer insanlardan sonra yeniliği görme $\bar{x}=2,91$ ) en düşük ortalamalara sahip olduğu belirlenmiştir. İşletme yöneticilerinin söz konusu ifadelerle ilgili duyarlı olmaları ve bunları geliştirmeleri gerektiği göz ardı edilmemelidir. 


\section{Değişkenler Arası Korelasyon Analizleri}

İki veya daha çok değişken arasında var olan ilişkinin büyüklüğünü, düzeyini ve yönünü tespit etmek için kullanılan istatistiksel metoda korelasyon denir. Nedensellik ile korelasyon birbirlerine yakın kavramlar olarak algılansa da farklı kavramlar olup araştırma yapana nedenselliğin sebebini bulmada ön bilgi verir (Gürbüz ve Şahin, 2014). Korelasyon analizinde ilişkinin varlığı korelasyon katsayısıyla bulunabilir. " $r$ " ile gösterilen korelasyon katsayısı -1 ile +1 arasında değerler almaktadır. Negatif değerler değişkenler arasında negatif yönlü bir ilişkiyi ifade ederken pozitif değerler doğru orantılı bir ilişkiyi ifade etmektedirler (Nakip, 2006:342-343). Açımlayıcı ve Keşfedici Faktör analizi ile belirlenen değişkenler arasındaki ilişkilerin bulunmasında "Pearson Korelasyon Analizi" kullanılmaktadır. Bu analizde r= “0,00-0,20 Çok Zayıf”, “0,20-0,40 Zayıf”, “0,40-0,60 Orta”, “0,60-0,80 Yüksek”, “0,80-1,00 Çok Yüksek" ilişki olduğu değerlendirilmektedir (Akgül ve Çevik, 2005:359). Bireysel yenilikçilik ve iş performansı arasındaki ilişkinin belirlenmesi amacıyla pearson korelasyon testi yapılmıştır.

Tablo 9: BY ve İP arasında korelasyon analizi

\begin{tabular}{|ll|l|l|}
\hline & BY & IP \\
\hline BY & Pearson & 1 &, $538^{* *}$ \\
& Sig. (2-kuyruk) & &, 000 \\
& N & 200 & 200 \\
\hline IIP & Pearson & $538^{* *}$ & 1 \\
& Sig. (2-kuyruk) & 000 & \\
& N & 200 & 200 \\
\hline
\end{tabular}

Tabloda görüldüğü üzere bireysel yenilikçilik ve iş performansı arasında $(\mathrm{r}=0,538)$ kuvvetinde $p<0,001$ anlamlılık düzeyinde pozitif yönlü orta düzeyde anlamlı bir ilişki vardır. Bu sonuç çalışanların iş performansında bireysel yenilikçiliğin önemli olduğunu göstermektedir. Bu önem işletme yöneticileri tarafından iyi anlaşılarak işletme amaç ve hedeflerine ulaşılmasında desteklenmelidir.

\section{Değişkenler arası Regresyon Analizi}

Regresyon analizinin yapılmasının gayesi; değişkenler arasındaki etkinin test edilmesi, iki değişkenden birinin değişiminin diğerindeki değişimi açıklanmasında kullanılan istatistiksel yöntemdir. Bu yöntem genellikle değişkenler arasındaki neden-sonuç ilişkisinin test edilebilmesinde kullanılmaktadır. Birden çok bağımsız değişken ile geçerli ve açıklayıcı modeller üretilebildiğinden dolayı sıklıkla kullanılan istatistiksel yöntemlerden biridir (Güriş ve Çağlayan, 2005: 199). Regresyon analizinde R:bağımlı değişken ile bağımsız değişkenler arasında olan korelasyonu, $\mathrm{R}^{2}$ : bağımlı değişkendeki değişimin bağımsız değişken tarafından ne kadarına kadar açıkladığı, F: yapılan regresyon analizinin anlamlı olup/olmadığını ( $\mathrm{p}<0,05$ den küçük olması), $\beta$ : bağımsız değişkenin etkisinin sabit tutularak bağımlı değişken üzerindeki etkisinin testinde kullanılmaktadır (Kalaycı, 2010:259-269). Araştırmanın bu kısmında bireysel yenilikçilik (BY) ve iş performansı (İP) arasındaki regresyon analizleri sunulmuştur. 
Tablo 10: Regresyon analizi

\begin{tabular}{|c|c|c|c|c|c|}
\hline \multirow[t]{2}{*}{ BY ile İP } & $\mathbf{R}$ & $\mathbf{R}^{2}$ & S.H. & $\mathbf{F}$ & $\mathbf{P}$ \\
\hline & 0,538 & 0,290 & 0,48865 & 80,709 & 0,000 \\
\hline \multirow{2}{*}{ Sabit } & B & S.H. & Beta & $\mathbf{t}$ & $\mathbf{P}$ \\
\hline & 2,026 & 0,239 & & 8,483 & 0,000 \\
\hline BY & ,615 & 0,068 & 0,538 & 8,984 & 0,000 \\
\hline \multicolumn{6}{|c|}{$\dot{I} P=2,026+0,615^{*}(B Y)$} \\
\hline \multirow{2}{*}{$\begin{array}{l}\text { Değişime direnç } \\
\text { - IIP }\end{array}$} & $\mathbf{R}$ & $\mathbf{R}^{2}$ & Tahmini S.H. & $\mathbf{F}$ & $\mathbf{P}$ \\
\hline & 0,007 & 0,000 & 0,57974 & 0,009 & 0,925 \\
\hline \multirow[t]{2}{*}{ Sabit } & B & S.H. & Beta & $\mathbf{t}$ & $\mathbf{P}$ \\
\hline & 4,137 & 0,132 & & 31,358 & 0,000 \\
\hline Değişime direnç & 0,005 & 0,049 & 0,007 & 0,094 & 0,925 \\
\hline \multicolumn{6}{|c|}{$\dot{I} P=4,137+0,005^{*}$ (Değișime direnç) } \\
\hline \multirow{2}{*}{ Fikir liderliği- İP } & $\mathbf{R}$ & $\mathbf{R}^{2}$ & Tahmini S.H. & $\mathbf{F}$ & $\mathbf{P}$ \\
\hline & 0,401 & 0,161 & 0,53099 & 38,035 & 0,000 \\
\hline \multirow{2}{*}{ Sabit } & $\beta$ & S.H. & Beta & $t$ & $\mathbf{P}$ \\
\hline & 3,040 & 0,184 & & 16,549 & 0,000 \\
\hline Fikir liderliği & 0,307 & 0,050 & 0,401 & 6,167 & 0,000 \\
\hline \multicolumn{6}{|c|}{$\dot{I} P=3,040+0,307^{*}$ (Fikir liderliği) } \\
\hline \multirow{2}{*}{$\begin{array}{l}\text { Deneyime } \\
\text { acıklık - IP }\end{array}$} & $\mathbf{R}$ & $\mathbf{R}^{2}$ & Tahmini S.H. & $\mathbf{F}$ & $\mathbf{P}$ \\
\hline & 0,480 & 0,231 & 0,50856 & 59,316 & 0,000 \\
\hline \multirow{2}{*}{ Sabit } & $\beta$ & S.H. & Beta & $t$ & $\mathbf{P}$ \\
\hline & 2,655 & 0,197 & & 13,456 & 0,000 \\
\hline Deneyime & 0,384 & 0,050 & 0,480 & 7,702 & 0,000 \\
\hline \multicolumn{6}{|c|}{$\dot{I} \bar{I} P=2,655+0,384^{*}$ (Deneyime açıklık) } \\
\hline \multirow{2}{*}{ Risk alma - İP } & $\mathbf{R}$ & $\mathbf{R}^{2}$ & Tahmini S.H. & $\mathbf{F}$ & $\mathbf{P}$ \\
\hline & 0,485 & 0,235 & 0,50713 & 60,771 & 0,000 \\
\hline \multirow[t]{2}{*}{ Sabit } & $\beta$ & S.H. & Beta & $t$ & $\mathbf{P}$ \\
\hline & 2,977 & 0,155 & & 19,255 & 0,000 \\
\hline Risk alma & 0,314 & 0,040 & 0,485 & 7,796 & 0,000 \\
\hline
\end{tabular}

Yapılan regresyon analizi bağımsız değişken bireysel yenilikçilik bağımlı değişken iş performansı üzerinde regresyon $(\beta=0,615 \quad p<0,05)$ sonucuyla bir etkiye sahip olduğu görülmektedir. Bu sonuçla " $\mathrm{H}_{1:}$ Bireysel yenilikçilik; iş performansı üzerinde anlamlı etkiye sahiptir " hipotezi kabul edilmiştir. Bu sonuç bireysel yenilikçiliğin işletme hedef ve amaçlarına ulaşılmasındaki örgütsel çıktılara etkileri açısından önemlidir. İşletme yöneticileri bu örgütsel çıtıların garanti altına almasında bireysel yenilikçiliği desteklemelidir. Yapılan regresyon analizi bağımsız değişken bireysel yenilikçilik alt faktörü "değişime direnç" bağımlı değişken iş performansı üzerinde regresyon $(\beta=0,005 \quad p>0,925)$ sonucuyla bir etkiye sahip olmadığı görülmektedir. Bu sonuçla " $H_{1 a:}$ Bireysel yenilikçiliğin alt faktörü değişime direnç; iş performansı üzerinde anlamlı etkiye sahiptir" hipotezi kabul edilmemiştir. Değişime direnç alt faktörüne ait ankette sorulan soruların negatif anlam barındırması sebebiyle katılımcıların olumsuz yönde etkilediği değerlendirilmiştir. Bu boyuta ait "yeni fikirlere kabulde temkinli olmak", "yeni icat ve düşüncelere karşı şüpheci olmak”, "yeni fikirlere itibar 
etmemek", "yenilikleri son kabul eden kişi olmak", "yeni yöntemleri kabulde isteksiz olmak", "eski usul ve yöntemlerin iyi olduğunu düşünmek" gibi ölçek ifadelerinin katılımcılar tarafından tam anlaşılmadığını göstermektedir. Kılıçer (2011), Özgür (2013), Pelenk (2017) ve Yılmaz (2019) çalışmalarında da benzer sonuçlar ifade edilmiştir. Değişime direncin; belirsizlik, güvensizlik, eksik bilgi, sosyo-ekonomik ve kültürel nedenlerden olduğu söylenebilir (Şimşek vd. ,1998: 248). Yapılan regresyon analizi bağımsız değişken bireysel yenilikçilik alt faktörü "fikir liderliği" bağımlı değişken iş performansı üzerinde regresyon $(\beta=0,307 p<0,05)$ sonucuyla bir etkiye sahip olduğu görülmektedir. Bu sonuçla "H1b: Bireysel yenilikçiliğin alt faktörü fikir liderliği; iş performansı üzerinde anlamlı etkiye sahiptir" hipotezi kabul edilmiştir. Bu sonuç bireysel yenilikçiliğin alt boyutu fikir liderliğinin iş performansındaki etkisi açısından önemlidir. Çünkü fikir ve düşünce yeniliğe dayanak olan kavramlardır. Yaptığı işle ilgili fikir ve düşünce üreterek bunu uç birim ürüne yönlendirebilen çalışanlar işletmeleri sürdürebilir kılabilirler. Yapılan regresyon analizi bağımsız değişken bireysel yenilikçilik alt faktörü "deneyime açılık" bağımlı değişken iş performansı üzerinde regresyon $(\beta=0,384 p<0,05)$ sonucuyla bir etkiye sahip olduğu görülmektedir. Bu sonuçla " $\mathbf{H}_{1 c \text { : }}$ Bireysel yenilikçiliğin alt faktörü deneyime açıklık; iş performansı üzerinde anlamlı etkiye sahiptir" hipotezi kabul edilmiştir. Bu sonuç öğrenmeye ve deneyime açık olmanın performansa etkisini göstermektedir. Deneyime açık olmak çalışanların dinamik yapısını korumayı ve kendini geliştirmeyi gerektirir. Dinamik ve kendini geliştiren çalışanlar yaptıklarıyla iş performansına katkı sağlayabilir. Yapılan regresyon analizi bağımsız değişken bireysel yenilikçilik alt faktörü "risk alma" bağımlı değişken iş performansı üzerinde regresyon $(\beta=0,314 p<0,05)$ sonucuyla bir etkiye sahip olduğu görülmektedir. Bu sonuçla " $\mathbf{H}_{1 \mathrm{c}}$ Bireysel yenilikçiliğin alt faktörü risk alma; iş performansı üzerinde anlamlı etkiye sahiptir" hipotezi kabul edilmiştir. Bu sonuç risk almanın önemini göstermesi açısından önemlidir. Kabul edilebilir riskler ne kadar alınırsa kazançlar da o kadar iyidir. Riskin az olduğu durumlarda potansiyel kazanç da düşük olacaktır. Özellikle belirsizlik ortamlarında yönetilebilir risk almak performansı da olumlu etkileyecektir.

Tablo 11: Hipotezlerin test edilmesi

\begin{tabular}{|l|l|l|l|}
\hline Hipotez & $\mathbf{t}$ & $\mathbf{P}$ & Sonuç \\
\hline $\begin{array}{l}\text { H1: Bireysel yenilikçilik; iş performansı üzerinde anlamlı } \\
\text { etkiye sahiptir }\end{array}$ & 8,984 & 0,000 & Kabul \\
\hline $\begin{array}{l}\text { H1a: Bireysel yenilikçiliğin alt faktörü değişime direnç; iş̧ } \\
\text { performansı üzerinde anlamlı etkiye sahiptir }\end{array}$ & 0,094 & 0,925 & Red \\
\hline $\begin{array}{l}\text { Hıb: Bireysel yenilikçiliğin alt faktörü fikir liderliği; iş̧ } \\
\text { performansı üzerinde anlamlı etkiye sahiptir }\end{array}$ & 6,167 & 0,000 & Kabul \\
\hline $\begin{array}{l}\text { Hıc: Bireysel yenilikçiliğin alt faktörü deneyime açılık; } \\
\text { iş performansı üzerinde anlamlı etkiye sahiptir }\end{array}$ & 7,702 & 0,000 & Kabul \\
\hline $\begin{array}{l}\text { H1d: Bireysel yenilikçiliğin alt faktörü risk alma; iş } \\
\text { performansı üzerinde anlamlı etkiye sahiptir }\end{array}$ & 7,796 & 0,000 & Kabul \\
\hline
\end{tabular}


Elde edilen bulgular ile literatürdeki bazı çalışmalar benzeşmektedir. Yuan ve Woodman (2010) çalışanların yenilikçi davranışlarının, iş performansını (beklenen olumlu performans sonuçları) ve kuruluşlarındaki imajı (beklenen imaj riskleri ve beklenen imaj kazanımları) etkilemesi için böyle bir davranışın beklentileri ile nasıl açıklandığını incelediği araştırmalarında her üç değişkeninin de yenilikçi davranışlar üzerindeki önemli etkileri olduğunu iddia etmişlerdir. Erdem vd. (2011) araştırmalarında yenilikçiliğin işletme performansını olumlu yönde etkilediğinden söz etmenin mümkün olduğunu ileri sürmüşlerdir. Akkoç vd. (2012) çalışmalarında gelişim kültürü ve lider desteğinin çalışanların yenilikçi davranışını artırdığını ve bu etkide iş-aile çatışmasının kısmi aracılık etkisi olduğunu iddia etmişlerdir. Çalışkan ve Akkoç (2012) araştırmalarında girişimci ve yenilikçi davranışın iş performansını pozitif yönde etkilediği ve bu etkide çevresel belirsizliğin aracılık etkisinin olduğu ileri sürmüşlerdir. Oktuğ ve Özden (2013) çalışmalarında içsel motivasyonun yalnızca "algılanan yeterlilik" boyutunun, bireycilik ile bireysel yenilikçilik eğilimi arasındaki ilişkiyi güçlendirdiğini iddia etmişlerdir. Çetin ve Taşdemir (2017) araştırmalarında bireysel yenilikçilik ile girişimcilik kapasitesi arasında orta düzeyde bir ilişki, girişimcilik niyeti ve girişimcilik kapasitesi arasında doğrusal ve zayıf bir ilişki tespit edilirken, bireysel yenilikçilik ile girişimcilik niyeti arasında çok zayıf bir ilişki olduğunu ileri sürmüşlerdir. Pelenk (2017) çalışmasında bireysel yenilikçiliğin "fikir liderliği ve risk alma" boyutlarının iş performansı üzerinde pozitif ve anlamlı etkiye sahip olduğunu, "değişime direnç" boyutunun ise iş performansı üzerinde negatif etkiye sahip olduğunu iddia etmiştir. Gürkaynak (2017) yeniliğe açıklık, uyumluluk, sorumluluk, duygusal denge ve kişilik özelliklerinin algılanan iş performansı ile anlamlı ilişkisi olduğunu belirlemiştir. Shanker vd. (2017) çalışmalarında Malezya şirketlerinde çalışan 202 yöneticiden oluşan anketten elde edilen bulgular neticesinde yenilikçi iş davranışının; organizasyonel iklim, yenilikçilik ve organizasyonel performans arasındaki ilişkide aracılık rolü oynadığını ileri sürmüştür. Işık ve Hajiyeva (2018) araştırmalarında bireysel yenilikçilik ve algılanan örgütsel destek arasında pozitif yönde anlamlı ilişkiler olduğunu ileri sürmüşlerdir. Boz vd., (2018) Örgütsel davranış ve yenilikçiliğin kalite yönetimi uygulamalarını pozitif yönde anlamlı şekilde etkilediğini tespit etmiştir. İspir (2018) çalışmasında iş tatmini ve yenilikçi davranışın, bireysel performansa olumlu yönde etkisinin olduğunu, ayrıca, iş tatmini, yenilikçi davranış ve bireysel performansın pozitif ilişki içerisinde olduğu belirlemiştir. Odacıŏ̆lu vd. (2018) çalışmalarında örgütsel yenilikçilik düzeyi ile algılanan performans arasında kuvvetli bir ilişki olduğu ve örgütün yenilikçilik düzeyinin algılanan performans üzerinde olumlu bir etkide bulunacağını ileri sürmüşlerdir.

\section{Sonuç ve Öneriler}

Yapılan bu çalışmanın amacı bireysel yenilikçiliğin iş performansı üzerindeki etkileşiminin belirlenmesidir. Bu amaçla Konya ilinde makine imalatı yapan bir işletmedeki beyaz ve mavi yakalı 200 gönüllü çalışana ulaşılmıştır. Özellikle imalat sektöründe çalışanların zorlu süreçlerin birikimiyle yetiştirildiği göz önüne alındığında bireysel yenilikçilik önem kazanmaktadır. Uzun vadeli işletme hedeflerine ulaşılmasında bireysel yenilikçilik, verimlilik, etkinlik ve sürdürülebilir işletme yaşamında önemli roller üstlenmektedir. Bu önemli rolün sağlanmasının yolu çalışanların yenilikçilik algıları ve neticesindeki iş performansına bağlıdır.

Elde ettiğimiz bulgularla bireysel yenilikçiliğin iş performansı üzerinde pozitif ve anlamlı etkisi $(\beta=0,615 ; p<0,05)$ tespit edilmiştir. Bireysel yenilikçiliğin alt boyutlarının fikir liderliği 
$(\beta=0,307 ; \mathrm{p}<0,05)$, deneyime açıklık $(\beta=0,384 ; \mathrm{p}<0,05)$ ve risk alma $(\beta=0,314 ; \mathrm{p}<0,05)$ sonucuyla iş performansı üzerinde anlamlı etkisi olduğu tespit edilmişken değişime direnç alt boyutunun $(\beta=0,005 ; p>0,05)$ sonucuyla anlamlı etkisi olmadığı belirlenmiştir.

Demografik değişkenlerden cinsiyetin; bireysel yenilikçilik $(t=-1,504 ; p>0,05)$ ve iş performansı $(t=-0,858 ; p>0,05)$ ile arasında herhangi bir anlamlı farklılığa rastlanmaz iken medeni durumu ile bireysel yenilikçilik $(t=2,979 ; p<0,05)$ ve iş performansı $(t=3,295 ; p<0,05)$ arasında anlamlı farklılığa rastlanmıştır. Ayrıca iş performansı konusunda 18-28 yaş aralığında çalışanların; 3946 ve 47-53 yaş aralığında çalışanlara göre $p<0,05$ anlamlılık düzeyinde negatif yönlü anlamlı farklılığ ile 1 yıl ve altı çalışanların 11-20 yıl arası çalışanlara göre $\mathrm{p}<0,05$ anlamlılık düzeyinde negatif yönlü anlamlı farklılık gösterdiği tespit edilmiştir. Elde edilen bulgular neticesinde anketteki en düşük genel ortalamaya sahip ifadeler baz alınarak hem işletme yöneticilerine hem de çalışanlarına şu önerilerde bulunulabilir;

- Yöneticilerin; yeni fikirlerin kabul edilmesinde temkinli davranmaması, çalışanların da ürettikleri fikirleri yöneticilerle paylaşabilmelerinin yolunu açacak örgütsel iklimin oluşturulması,

- Yönetici ve çalışanların yeni icatlara ve düşüncelere şüpheyle yaklaşmalarını önleyecek paydaş yönelimli işletme uygulamalarının inşa edilmesi,

- Yönetici ve çalışanların yeni düşünce ve fikirleri büyük çoğunluğun kabul etmesine kadar yeni fikirlere itibar etmeyi beklememeleri,

- Yönetici ve çalışanların yeni fikir ve düşünceleri en son kabul eden kişiler olmamasının sağlanması,

- Çalışanların çevresindeki bireylerde işe yaradığını görene kadar bir işi yapmanın yeni yollarını kabul etmekteki isteksizliğini ortadan kaldıracak iletişim kanallarının kurulması,

- Çalışanların eski usul ve yöntemlerle iş yapmanın en iyisi olduğu düşüncesinin dönüştürülmesi için uygun işletme içi/dışı eğitimlere gönderilmesi,

- Yöneticiler tarafından çalışanları kapsayan bilgilendirme ve bilinçlendirme faaliyetlerinde yeniliklerin içselleştirmesini sağlayacak işletme politikalarının geliştirilmesi,

- Yönetici ve çalışanların yeni fikirlere karşı şüphelerini gidermek için bireysel öneri sistemlerinin etkin kullanılması,

- Çalışanlar arasında dikey, yatay ve çapraz iletişim kanallarının etkin kullanılması,

- Çalışanların yaratıcılık ve yenilikçilik eğilimlerinin işletme yararına kullanılmasındaki engellerin kaldırılması,

- Çalışanların belirsizlikten kaçınma ile ilgili işletme içi/dışı eğitim programları hazırlanması,

- Yönetici ve çalışanların işle alakalı olmayacak şekilde sosyal medya kullanımının engellenmesi önerilebilir.

$\mathrm{Bu}$ araştırma Konya'da bulunan makine imal eden bir işletmede yapılmıştır. Bireysel yenilikçilik ve iş performansı alanlarında yapılmış pek çok araştırma bulunmakta iken özellikle bireysel yenilikçiliğin iş performansına etkisini inceleyen çalışma sayısı azdır. Bu konu ile ilgili gelecekte yapılacak ulusal ve uluslar arası çapta diğer sektörlerle karşılaştırmalı çalışmalar yapılmasının uygun olacağı değerlendirilmektedir. 


\section{Kaynakça}

Agarwal, Ritu Ve Prasad, Jayesh (1998). “A Conceptual And Operational Definition Of Personal Innovativeness In The Domain Of Information Technology". Information Systems Research, Vol. 9(2), Ss. 204-215.

Akal, Zühal (1992). İşletmelerde Performans Ölçüm Ve Denetimi: Çok Yönlü Performans Göstergeleri. Ankara: Mpm Yayınları.

Akal, Zühal (2000). İşletmelerde Performans Ölçüm Ve Denetimi, Milli Prodüktivite Merkezi, 4. Baskı. Ankara.

Akgül, Aziz, Çevik, Osman (2005). İstatistiksel Analiz Teknikleri-Spss'te İşletme Yönetimi Uygulamaları, Emek Ofset Ltd.Şti., Ankara.

Akkoç, İrfan, Çalışkan, Abdullah Ve Turunç, Ömer (2012). “Örgütlerde Gelişim Kültürü Ve Algılanan Örgütsel Desteğin İş Tatmini Ve İş Performansına Etkisi: Güvenin Aracılık Rolü", Yönetim Ve Ekonomi: Celal Bayar Üniversitesi İibf. Dergisi, 19(1), Ss. 105-135.

Barıranı, Ahmad, Beaudry, Catherine Ve Agard, Bruno (2015). “Distans Recombination And The Creation Of Basic Inventions: An Analysis Of The Diffusion Of Public And Private Sector Nanotechnology Patents İn Canada". Technovation (36), Pp. 39-52.

Baş, Melih Ve Artar, Ayhan (1991). İşletmelerde Verimlilik Denetimi Ölçme Ve Değerlendirme Modelleri. Ankara: Mpm Yayınları, Ss. 302-435.

Bhatnagar, Amit, Misra, Sanjog Ve Rao, H.Raghav (2000). “On Risk, Convenience And İnternet Shopping Behavior", Communications Of The Acm, 43(11), Pp. 98-105.

Blake, F.Brain, Neuendorf, A.Kimberly Ve Valdıserrı, M.Colin (2003). “Inovativenessand Variety Of Internet Shopping", Internet Resarch: Electronic Networking And Applications And Policy, 13 (3), Pp. 156-169.

Borman, C.Walter Ve Motowidlo, J.Stephan (1993). Expanding The Criterion Domain To Include Elements Of Contextual Performance, Personnel Selection In Organizations, Derl. Schmitt, N. Ve Borman, W.C., San Francisco, Ca: Josseybass, Pp. 71-98.

Boz, Dursun, Duran, Cengiz Ve Behdioğlu, Sema (2018). “Örgütsel Vatandaşlık Davranışı Ve Örgütsel Yenilikçiliğin Toplam Kalite Yönetimi Uygulamaları Üzerindeki Etkileri". Dumlupınar Üniversitesi Sosyal Bilimler Enstitüsü Dergisi, (58): Ss.160-184.

Büyüköztürk, Şener (2007). Sosyal Bilimler İçin Veri Analizi El Kitabı, 7. Baskı, Ankara: Pegem Akademi Yayıncilik.

Çalık, Temel (2003). Performans Yönetimi Tanımlar, Kavramlar, İlkeler Gündüz Eğitim Ve Yayıncllık, Ankara.

Çalışkan, Abdullah Ve Akkoç, İrfan (2012). “Girişimci Ve Yenilikçi Davranışın İş Performansına Etkisinde Çevresel Belirsizliğin Rolü”, Çağ Üniversitesi Sbe. Dergisi, 9(1), Haziran 2012: Ss. 1-29.

Çetin, Onur Ve Taşdemir, Özgür (2017). “Girişimcilik Kapasitesi Ve Bireysel Yenilikçiliğin Girişimcilik Niyeti Üzerine Etkisi". Sosyal Bilimler Araştırma Dergisi, 6(3): Ss. 76-87.

Doğan, Yasemin (2005). Organizasyonlarda Pozitif Ve Negatif Duygusallığın Çalışanların Görev Ve Bağlamsal Performansları Üzerine Etkisini Belirlemeye Yönelik Kayseri'de Bir Araştırma. (Yayınlanmamış Yüksek Lisans Tezi), Erciyes Üniversitesi Sbe.,Kayseri. 
Erdem, Barış, Gökdeniz, Ayhan Ve Met, Önder (2011). “Yenilikçilik Ve İşletme Performansı İlişkisi: Antalya'da Etkinlik Gösteren 5 Yıldızlı Otel İşletmeleri Örneği". Dokuz Eylül Üniversitesi İibf. Dergisi, Cilt:26, Sayı:2, Yı1:2011, Ss.77-112.

Erdemir, Sümeyye (2013). İlköğretim Öğretmenlerinin Duygusal Zekâ Düzeyleri İle Yaşadıkları Psikolojik Yıldırma (Mobbing) Arasındaki İlişki Üzerine Bir Araştırma, (Yüksek Lisans Tezi), Gaziantep Üniversitesi, Gaziantep.

Erkoç, İdil Çağıl (2015). Algılanan Örgütsel Destek Ve İş Performansı Arasındaki İlişkide Öz Yeterlilik Faktörünün Düzenleyici Rolü: Bankacılık Sektöründe Bir Araştırma. (Yayımlanmamış Yüksek Lisans Tezi), İstanbul Kültür Üniversitesi, İstanbul.

Field, Andy (2007). Discovering Statistics Using Spss., Sage Publications Ltd., Uk: London.

Goodman, Scott A. Ve Svyantek, Daniel J. (1999). “Person-Organization Fit And Contextual Performance: Do Shared Values Matter". Journal Of Vocational Behavior, 55(2), Pp. 254-275.

Güleş, Hasan Kürşat Ve Bülbül, Hasan (2004). Yenilikçi İ̧sletmeler İçin Stratejik Rekabet Aracı, Nobel Yayın Dağıtım, Ankara.

Gürbüz, Sait Ve Şahin, Faruk (2014). Sosyal Bilimlerde Araştırma Yöntemleri, 1.Baskı, Seçkin Yayıncilik, Ankara.

Güriş, Selahattin Ve Çağlayan, Ebru (2005). Ekonometri, Der Yayınları, İstanbul.

Gürkaynak, Burcu (2017). Çalışan İş Performansının Değerlendirilmesinde İnsan Kaynakları Yönetimi Uygulamalarmın Etkililiği Ve Kişilik Özelliklerinin Rolü Üzerine Bir Araştırma, (Yüksek Lisans Tezi), Başkent Üniversitesi Sosyal Bilimleri Enstitüsü. Ankara.

Greenhalg, Trisha, Robert, Gleen Ve Bate, Paul, Macfarlane, Fraser Ve Kyriakıdou, Olivia (2008). Diffusion Of Innovations In Health Service Organizations: A Systematic Literature Review, John Wiley Sons, Chichester.

Hirschman, Elizabeth C. (1980). "Innovativeness, Novelty Seeking, And Consumer Creativity", Journal Of Consumer Research, Vol.V11, No:3, 1980, Pp. 283-295

Hurt, H.Thomas., Joseph, Katherine Ve Cook, D.Chester (1977). “Scales For The Measurement Of Innovativeness", Human Communication Research, 4(1), Pp. 58-65.

Işık, Cem Ve Hajiyeva, Tahmina (2018). "Bireysel Yenilikçilik Ve Algılanan Örgütsel Destek Düzeyi İlişkisi: İstanbul Otelleri Örneği”. Güncel Turizm Araştırmaları Dergisi, 2(2), Ss. 206-227.

İspir, İsa (2018). “Çalışanların İş Tatmini İle Yenilikçi Davranışının Bireysel Performansa Etkisi”. Inönü University International Journal Of Social Sciences (Inijoss), 7(2-14), Ss. 120-135.

Jamrog, Jay, Vickers, Mark Ve Bear, Donna (2006). "Building And Sustaining A Culture That Supports İnnovation". People And Strategy, 29(3), Pp. 9-19.

Jawahar, I. M. Ve Carr, Dean (2007). “Conscientiousness And Contextual Performance The Compensatory Effects Of Perceived Organizational Support And Leader Member Exchange", Journal Of Managerial Psychology,(22), Pp. 330-349.

Jong, Jeroen P.J. Ve Hartog, Den N. (2008). Innovative Workbehavior Measurementand Validation, Http://Www.Ondernemerschap.Nl/Pdfez/H200820.Pdf (Erişim Tarihi, 01.06.2020).

Jorde, Thomas Ve Teece, David (1989). Innovation, Cooperation And Antitrust, Oxford University Press, New York. 
Kalaycı, Şeref (2010). Spss Uygulamalı Çok Değişkenli İstatistik Teknikleri, 5.Baskı., Asil Yayın Dağıtım, Ankara.

Kılıç, Gülten (2006). Eğitim Kurumlarında Liderlik Tarzları Ve Örgüt Kültürünün Performans Üzerindeki Etkisi. (Yayımlanmamış Yüksek Lisans Tezi), Erciyes Üniversitesi Sosyal Bilimler Enstitüsü, Kayseri.

K1lıçer, Kerem (2011). Bilgisayar Ve Öğretim Teknolojileri Eğitimi Öğretmen Adaylarmın Bireysel Yenilikçilik Profilleri, (Yayımlanmamış Doktora Tezi), Anadolu Üniversitesi Eğitim Bilimleri Enstitüsü, Eskişehir.

Kurt, Esra (2013). Alg̨lanan Sosyal Destek Ve İş Performansı İlişkisinde İşe Bağlılı̆̆ın Aracı Etkisi: Turizm İşletmelerinde Bir Araştırma. (Yayımlanmamış Yüksek Lisans Tezi), Hacettepe Üniversitesi, Ankara.

Leavitt, Clark Ve Walton, John (1975). "Development Of A Scale For Innovativeness", Advances İn Consumer Research, 2, Pp. 545-554.

Lu, June, James E.Yao Ve Chun-Sheng Yu (2005). “Personal Innovativeness, Social Influences And Adoption Of Wireless Internet Services Via Mobile Technology". Journal Of Strategic Information Systems, Vol. 14, No: 3, 2005, Pp. 245-268.

Mclean, Laird D. (2005). “Organizational Cultures Influence On Creativity And Innovation: A Review Of The Literature And Implications For Human Resource Development", Advances In Developing Human Resources, 7(2), Pp. 226-246.

Nakip, Mahir (2006). Pazarlama Araştırmaları Teknikler Ve Uygulamalar, Seçkin Yayınevi, Ankara.

Neely, Andy Ve H11, Jasper (1998). Innovation And Business Performance: A Literature Review. The Judge Institute Of Management Studies, University Of Cambridge. Pp. 01-65.

Odacıoğlu, Yaşar, Kırılmaz, Harun Ve Uyanık, Kaan Can (2018). “Örgütsel Yenilikçilik Düzeyinin Algılanan Performans Üzerine Etkileri", Eskişehir Osmangazi Üniversitesi Hastanesinde Bir Uygulama. Organizasyon Ve Yönetim Bilimleri Dergisi, 10(1), Ss. 72-86.

Oktŭg, Zeynep Ve Özden, Melis Saray (2013). “Bireycilik/Toplulukçuluk İle Bireysel Yenilikçilik Eğilimi Arasındaki İlişkide İçsel Motivasyonun Biçimlendirici Rolü", Eskişehir Osmangazi Üniversitesi Sosyal Bilimler Dergisi, 14(2). Ss. 1-22.

Orhan, Nazife (2012). Bankacıllk Sektöründe Duygusal Zeka Ve Yenilikçi İş Davranışlarının İş Tatmini Üzerine Etkileri, (Yüksek Lisans Tezi), Beykent Üniversitesi, İşletme Yönetimi Abd., İstanbul.

Özdemir, Onur (2017). Lider Desteği Ve Örgütsel Adalet Algısının İş Performansına Etkisinde Kişi- Örgüt Uyumunun Aractlı Rolü: Eğitim Sektöründe Bir Araştırma, (Yüksek Lisans Tezi). Türk Hava Kurumu Üniversitesi. Ankara.

Özer, Erdal (2018). Otel Yiyecek İçecek Bölümlerinde Güçlendirmenin İşgören Performansina Ve İşten Ayrılma Niyetine Etkisi: Afyonkarahisar'daki Beş Yıldızlı Otel İşletmelerinde Bir Uygulama, (Yayınlanmamış Doktora Tezi), Adnan Menderes Üniversitesi Sosyal Bilimler Enstitüsü Müdürlüğü, Aydın.

Özgür, Hasan (2013). “Bilişim Teknolojileri Öğretmen Adaylarının Eleştirel Düşünme Eğilimleri İle Bireysel Yenilikçilik Özellikleri Arasındaki İlişkinin Çeşitli Değişkenler Açısından İncelenmesi", Mersin Üniversitesi Ĕ̆itim Fakültesi Dergisi, Cilt 9(2), Ss. 409-420. 
Pelenk, Saadet Ela (2017). “Bireysel Yenilikçi Davranışların Bireysel İş Performansı Üzerindeki Etkisi: Teknoloji Çalışanları Üzerinde Bir Araştırma". Joeep: Journal Of Emerging Economics And Policy,2(2), Ss. 2-14.

Rogers, Everett M. (1995). Diffusion Of Innovations, Publishing Co., Macmillian.

Safaria, Triantora, Othman, Ahmad Bin Ve Wahab, Muhammad Nubli Abdul (2010). "Religious Coping, Job Insecurity And Job Stress Among Javanese Academic Staff: A Moderated Regression Analysis". University Malaysia Pahang, Malaysia, International Journal Of Psychological Studies Vol. 2(2), Pp. 159-169.

Shanker, Roy, Bhanugopan, Ramudu, Heijden Van Der B.I. Ve Farrell, Mark (2017). “Organizational Climate For İnnovation And Organizational Performance: The Mediating Effect Of İnnovative Work Behavior". Journal Of Vocational Behavior, 100: Pp. 67-77.

Sonnentag, Sabine Ve Frese, Michael (2002). Performance Concepts And Performance Theory. Psychological Management Of İndividual Performance, 23(1), Pp. 3-25.

Şahin, Ayşe (2011). “Mersin'de Faaliyet Gösteren Küçük Ve Orta Büyüklükteki İşletmelerin Yenilik Faaliyetlerinin Ölçülmesi". Doğuş Üniversitesi Dergisi, 10(2), Ss. 259-271.

Şimşek, Mehmet Şerif, Çelik, Adnan Ve Akgemici, Tahir (1998). Davranış Bilimlerine Giriş Ve Örgütlerde Davranış. Nobel Yayın Dağıtım, Ankara.

Şimşek, Mehmet Şerif (2002). Yönetim Ve Organizasyon, Günay Ofset, Konya.

Topcu, Mustafa Kemal., Gürsoy, Ali Ve Gurson, Poyraz (2015). “The Role Of The Servant Leadership On The Relation Between Ethical Climate Perception And Innovative Work". European Research Studies, 18(1), Ss. 67-80.

Uzkurt, Cevahir (2008). Pazarlamada Değer Yaratma Aracı Olarak Yenilik Yönetimi Ve Yenilikçi Örgüt Kültürü, Beta Basım Yayını, İstanbul.

Ünlü, Onur Ve Yürür, Senay (2011). “Duygusal Emek, Duygusal Tükenme Ve Görev/ Bağlamsal Performans İlişkisi: Yalova' da Hizmet Sektörü Çalışanları İle Bir Araştırma". Erciyes Üniversitesi İktisadi Ve İdari Bilimler Fakültesi Dergisi, Sayı: 37, Ss. 183-207.

Wan-Jing, April Chang Ve Tung, Chun Huang (2011). "Relationship Between Strategic Human Resource Management And Firm Performance", International Journal Of Manpower, Vol. 26(5), Pp. 434-449.

Yılmaz, Oğuz (2019). Öğretmenlerin Bit Entegrasyon Yaklaşımları, Teknoloji Entegrasyonuna Yönelik Öz-Yeterlik Algısı Ve Bireysel Yenilikçilik Özellikleri Arasındaki İlişkiler, (Yayınlanmamış Yüksek Lisans Tezi), Necmettin Erbakan Üniversitesi, Eğitim Bilimleri Enstitüsü, Konya.

Yuan, Feirong Ve Woodman, Richard W. (2010). “Innovative Behavior İn The Workplace: The Role Of Performance And İmage Outcome Expectations". Academy Of Management Journal, 53(2), Pp. 323-342.

Yeloğlu, Hakkı Okan (2007). “Örgüt, Birey, Grup Bağlamında Yenilik Ve Yaratıcılık Tartışmaları”. Ege Akademik Bakış, 7(1), Ss. 133-152.

Yüksel, Sadık Murat (2015). Türkiye'deki İşletmelerin Yenilikçilik Yeteneklerini Etkileyen Faktörlerin Analizi, (Yayınlanmamış Doktora Tezi), Kara Harp Okulu Savunma Bilimleri Enstitüsü, Ankara.

Htpp://Www.Tdk.Org.Tr (19.05.2019). 